Ege Tıp Dergisi / Ege Journal of Medicine 2017;56(4):183-192

\title{
Meme kanseri kök hücrelerinde elajik asit ile indüklenmiş miRNA'ların ifadesi ve elajik asidin apoptoz üzerine etkisi
}

Ellagic acid induced expression of miRNAs in breast cancer stem cells and effect of ellagic acid on apoptosis

Hasan Onur Çağlar ${ }^{1}$ Sunde Yılmaz Süslüer ${ }^{2} \quad$ Şebnem Kavaklı ${ }^{3} \quad$ Cumhur Gündüz $^{2}$

Biray Ertürk $^{4} \quad$ Ferda Özkınay ${ }^{4} \quad$ Ayfer Haydaroğlu ${ }^{5}$

${ }^{1}$ Ege Üniversitesi, Sağlık Bilimleri Enstitüsü, Kök Hücre Anabilim Dalı, İzmir, Türkiye

${ }^{2}$ Ege Üniversitesi Tıp Fakültesi, Tıbbi Biyoloji Anabilim Dalı, İzmir, Türkiye

${ }^{3}$ Ege Üniversitesi, Fen Bilimleri Enstitüsü, Biyoteknoloji Anabilim Dalı, İzmir, Türkiye

${ }^{4}$ Ege Üniversitesi Tıp Fakültesi, Tıbbi Genetik Anabilim Dalı, İzmir, Türkiye

${ }^{5}$ Ege Üniversitesi Tıp Fakültesi, Radyasyon Onkolojisi Anabilim Dalı, İzmir, Türkiye

\section{Öz}

Amaç: Östrojen bağımlı meme kanseri tümör oluşumunda etkili miRNA'lar elajik asit (EA) uygulaması ile baskılanmaktadır. Ancak, EA uygulamasından sonra meme kanseri kök hücrelerindeki (MKKH) miRNA'ların ifade profillerinin düzenlenmesi hala belirsizdir. Bu çalışmada, MKKH'lerde EA-indüklenmiş apoptozun gösterilmesi ve EA uygulamasından sonra değişen miRNA ifade profilinin belirlenmesi amaçlanmıştır.

Gereç ve Yöntem: EA'nın MKKH'lerdeki sitotoksik etkisi WST-1 testi ile incelendi. EA uygulamasından sonra apoptoz ve hücre döngüsü analizleri flow sitometri ile yapıldı. EA uygulamasından sonra, MKKH'lerin miRNA ifade profilleri RT-PCR miRNA array ile tanımlandı.

Bulgular: MKKH'ler üzerinde EA'nın sitotoksik etkisi saptandı. 48. ve 72. saatlerde EA'nın IC50 konsantrasyonu 24.8 $\mu M$ 'dı. EA, MKKH'lerde apoptozu indüklemedi. Bununla beraber, EA'nın 24., 48. ve 72. saat uygulamalarında $S$ fazı bloğu gözlendi. Toplamda 84 miRNA geninin 76'sının ifade profili belirlendi. hsa-miR-125b-1-3p'nin ifadesi EA uygulanmasıyla 3.59 kat arttı. Let-7 ve miR-200 aileleri dahil diğer tüm miRNA'ların ifade profili EA uygulaması nedeniyle azalış gösterdi.

Sonuç: Bu çalışmada, EA'nın MKKH'de apoptozu etkilemediği ve hsa-miR-125b-1-3p'in ifadesini arttıırken, başta hsa-miR-485-5p ve hsa-miR-328-3p olmak üzere diğer miRNA'ların ifadesinde düşmeye neden olduğu görüldü. Anormal miRNA ifade profili nedeniyle MKKH'lerin EA uygulamasına direnç gösterebileceği düşünüldü.

Anahtar Sözcükler: Elajik asit, meme kanseri kök hücreleri, miRNA, apoptoz.

\section{Abstract}

Aim: miRNAs which are associated with estrogen dependent tumorigenesis of breast cancer are suppressed by ellagic acid (EA) treatment. However, modulation of expression profiles of miRNAs in breast cancer stem cells (BCSCs) after EA treatment is still unclear. In this study, it was aimed to show EA-induced apoptosis in BCSCs and to determine altered expression profiles of miRNAs after EA treatment.

Materials and Methods: Cytotoxic effects of EA on BCSCs were examined by WST-1 reagent test. Apoptosis and cell cycle analysis after EA treatment were detected by flow cytometry analysis. After EA treatment, miRNA expression profiles of BCSCs were determined by RT-PCR miRNA array.

Results: Cytotoxic effect of EA on BCSCs was found. IC50 concentration of EA at 48th and 72nd hours was 24.8 $\mu M$. EA did not induce apoptosis in BCSCs. In addition, S phase arrest was observed at 24th, 48th, 72nd hours of EA treatment. Expression profiles of 76 of totally 84 miRNA genes were detected. Expression of hsa-miR-125b-1-3p was increased as 3.59 folds by EA treatment. Expression profiles of all the others miRNAs, including members of Let-7 and miR-200 families, showed a decrease due to EA treatment.

Yazışma Adresi: Hasan Onur Çağlar

Ege Üniversitesi, Sağlık Bilimleri Enstitüsü, Kök Hücre Anabilim

Dalı, İzmir, Türkiye

Makalenin Geliş Tarihi: 08.09.2016 Kabul Tarihi: 14.12.2016 
Conclusion: In this study, it was observed that EA leads to upregulated expression of hsa-miR-125b-1-3p in contrast to downregulated expression of all other miRNAs, especially hsa-miR-485-5p and hsa-miR-328-3p, and does not induce apoptosis in BCSCs. It was suggested that BCSCs may show resistance to EA treatment due to aberrant expression profiles of miRNAs.

Keywords: Ellagic acid, breast cancer stem cells, miRNAs, apoptosis.

\section{Giriş}

Meme kanseri kadınlar arasında en sık gözlenen kanserlerden biridir. Solunum yolu ve akciğer kanserlerinden sonra, meme kanseri kadınlar arasında kanser ilişkili ölümlerin başında yer almaktadır (1). Meme kanseri tümörleri uygulanan tedaviye karşı direnç gösterebilmektedir (2-4). Direnç oluşumu ile birlikte, meme kanseri hastalarında tümör yalnızca primer bölge ile sınırlı kalmamakta ve farklı bölgelere metastaz yapabilmektedir (5). Meme kanserinin insidans ve mortalite oranlarının yüksek olması ayrıca tedavi etkinliğindeki sınırlılıklar nedeniyle yeni kimyasal ajanlarının araştırılmasına intiyaç duyulmaktadır. Bitkisel doğal fenolik bileşiklerin kanser hücreleri üzerindeki bölünmeyi durdurucu etkisi, bu tür bileşiklerin uygulanan mevcut kanser tedavisine ek olarak kullanılabilme potansiyeline dikkat çekmektedir.

Elajik asit (ellagic acid, EA) Myrciaria cauliflora, Juglans regia, Terminalia chebula, Sanguisorba officinalis, Punica granatum gibi bitkilerin yaprak, meyve ve tohumlarından elde edilebilen fenolik bir bileşiktir (6-10). Bitkilerde ikincil metabolit olarak oluşan elajitaninler'in (ellagitannins) hidrolizi sonucu oluşan EA, antiinflamatuar ve anti-oksidan özelliklere sahiptir (11-13) Birçok çalışma, EA içeren bitki ekstraktlarının birçok farklı kanser hücresi için proliferasyonu baskılayıcı bir etkiye sahip olduğunu göstermiştir $(6,10)$. EA'nın MCF-7 meme kanseri hücrelerine uygulanması apoptozu indüklediği gibi hücre döngüsünü de bloke etmektedir (14). Meme kanseri hücrelerinde, EA TGF- $\beta /$ Smads ve $\mathrm{PI3K} / \mathrm{AKT} / \mathrm{mTOR}$ sinyal yolakları ile ilişkili genlerin ifadesini yeniden düzenleyerek hücre bölünmesine etki etmektedir (14-16). Hücre bölünmesini baskılayıcı özelliğine ek olarak, EA vasküler endotelyal büyüme faktörü reseptörünün aktivesini inhibe ederek meme kanseri tümör hücrelerinin göçünü ve yeni damar oluşumunu engellemektedir (17). Bir kimyasal bileşiğin etkisi tümör dokusu içerisindeki farklı popülasyonlara göre değişebilmektedir. EA'nın etkinliği in vitro ve in vivo olarak meme kanseri hücrelerinde gösterilmiş olmasına rağmen meme kanseri kök hücrelerindeki etkinliği hala belirsizdir.

Kanser kök hücreleri, tümör dokusu içerisinde oldukça az bir oranda bulunan ve kök hücre benzeri davranış sergileyen hücrelerdir (18). Kanser hücrelerine kıyasla, kanser kök hücrelerinin immün sistemi baskılanmış farelerdeki tümör oluşturma kapasitesi daha yüksektir. Hücre döngüsü, DNA onarımı, ilaç metabolizması gibi çeşitli hücresel mekanizmalarla ilişkili genlerin ifadesi kanser kök hücreleri ve kanser hücreleri arasında farklılıklar göstermektedir $(18,19)$. Hücre sinyal yolakları ile ilişkili gen ifadelerinin kanser kök hücrelerinde yeniden düzenlenmesi, tedavi ajanlarına karşı daha fazla direnç gözlenmesine neden olmaktadır $(18,19)$. Bu nedenle, konvansiyonel kanser tedavisine ek olarak kullanılabilecek ajanların kanser kök hücreleri üzerindeki etkinliğinin araştırılması gereklidir.

Hücre sinyal yolakları ile ilişkili genlerin ifadesi çeşitli mekanizmalar yoluyla yeniden düzenlenmektedir. miRNA'lar 11 22 nükleotid uzunluğundaki protein kodlamayan RNA molekülleridir. miRNA'lar hedefindeki mRNA'ların 3'UTR bölgesine bağlanarak protein ürününe dönüşmesini engellemektedir. Protein kodlayan genlerin ifade kontrolünde rol oynayan miRNA genleri, normal meme dokusu ve meme kanseri hücreleri arasında ifade farklılıkları sergilemektedir (19). Bununla birlikte, bu farklılık meme kanser hücreleri ve kanseri kök hücreleri arasında da gözlenmektedir (20). Meme kanseri kök hücrelerinde, hücre apoptozunu indükleyici ve hücre bölünmesini inhibe eden miRNA ifadelerinin azaldığı bilinmektedir (21). Fare meme karsinogenez modelinde, EA'nın östrojen ilişkili tümör oluşumunda etkili olan anormal miRNA ifadelerini tersine çevirdiği gösterilmiştir (22). EA'nın meme kanseri kök hücrelerindeki miRNA ifadesini nasıl düzenlediği henüz bilinmemektedir. Meme kanseri kök hücrelerinde sinyal yolaklarının farklı düzeydeki aktivasyonu, EA'nın bu hücrelerdeki miRNA ifadesi üzerinde daha farklı bir etki oluşturmasına neden olabilir. $\mathrm{Bu}$ çalışma, EA uygulamasına bağlı olarak meme kanseri kök hücrelerindeki miRNA ifade değişimlerini ortaya çıkartmayı amaçlamıştır.

\section{Gereç ve Yöntem}

\section{Hücre kültürü}

İnsan kökenli meme kanseri kök hücreleri $75 \mathrm{~cm}^{2}$ lik flask içerisinde direkt kültüre hazır bir şekilde CelProgen firmasından (San Pedro, CA, USA) temin edildi. Temin edilen meme kanseri kök hücreleri CD113, CD44, SSEA3/4, Oct-4, alkalin fosfataz ve aldehid dehidrogenaz gibi kök hücre belirteçleri bakımından pozitif özellik göstermektedir (CelProgen, Kat No: 3610229-T75, San Pedro, CA, USA). Meme kanseri kök hücrelerinin kültürü için serum ve diğer büyüme faktörlerini içeren Human Breast Cancer Stem Cell Complete Growth Media ortamı (CelProgen, San Pedro, CA, USA) kullanıldı. Meme kanseri kök hücreleri $\% 5$ 
$\mathrm{CO}_{2}$ içeren nemli atmosferde $37^{\circ} \mathrm{C}$ sıcaklıkta inkübe edildi.

\section{WST-1 testi ile sitotoksitenin belirlenmesi}

EA'nın, meme kanseri kök hücreleri üzerindeki sitotoksik etkisinin belirlenmesi için WST-1 testi (Boster Biological Technology, CA, USA) kullanıldı. Çalışma öncesinde 96'lık kuyucuklu plakalara hücreler her bir kuyuda 10.000 hücre olacak şekilde aktarıldı. EA'nın, meme kanseri kök hücreleri üzerindeki sitotoksitesi doz ve zaman bağımlı olarak ölçüldü. EA (50 mg, Fluka, Sigma, USA) $165 \mu \mathrm{L}$ DMSO içerisinde çözülerek $1 \mathrm{M}$ ana stok hazırlandı. EA'nın farklı konsantrasyonları $(100 \mu \mathrm{M}-1,6$ $\mu \mathrm{M}) 24,48$ ve 72 saat boyunca meme kanseri kök hücrelerine uygulandı. İnkübasyon süresi dolduğunda, hücrelere WST-1 karışımından $10 \mu \mathrm{L}$ eklendi. Bir saat boyunca kuyucuklu plakalar inkübatörde inkübe edildi. WST-1 ajanı ile inkübasyondan sonra, örneklerin $450 \mathrm{~nm}$ dalga boyundaki absorbans değerleri ELISA okuyucu (Thermoscientific, Multiskan FC, Finland) ile alındı. Referans dalga boyu $620 \mathrm{~nm}$ olarak belirlendi. EA'nın uygulanmadığı hücrelerden elde edilen absorbans değerleri kontrol olarak veri normalizasyonunda kullanıldı.

\section{Flow sitometri ile apoptozun belirlenmesi}

Flow sitometri ile apoptozun belirlenmesi için meme kanseri kök hücreleri 6'lı kuyucuklu plakalara her bir kuyusunda 100.000 hücre olacak şekilde ekildi. EA için saptanan $\mathrm{IC}_{50}$ konsantrasyonu apoptoz çalışmasında hücrelere uygulandı. EA uygulanmayan hücreler ise kontrol grubu olarak kullanıldı. EA uygulanan ve uygulanmayan hücreler tripsin ile kaldırılarak steril falkon tüplerine alındı. Tripsin inaktivasyonu için tüplere serum içeren ortam eklendi. Hücreler 1000 g'de 10 dakika boyunca santrifüj edildi ve süpernatant alındı. Hücreler 1X PBS ile iki kez yıkandıktan sonra örneklere 1X bağlanma tamponu eklendi. Bağlanma tamponu çekilmeden, örneklere $5 \mu \mathrm{L}$ Annexin-V/PE eklendi (BD bioscience, pharmigen, USA). Örnekler 15 dakika boyunca oda sıcaklığında karanlıkta inkübe edildi. Örnekler 1 saat içerisinde flow sitometride (BD Accuri C6 flow cytometry, Becton-Dickinson, USA) okundu. Analiz için Cell Quest Software (Becton-Dickinson, USA) yazılımı kullanıldı.

\section{Hücre döngüsünün belirlenmesi}

Meme kanseri kök hücreleri 6'lı kuyucuklu plakalara her bir kuyuda 100.000 hücre olacak şekilde ekildi. Hücre döngüsünün belirlenmesinde, $E A^{\prime}$ nın belirlenen $I_{50}$ konsantrasyonu hücrelere uygulandı. EA uygulanmayan hücreler kontrol olarak kullanıldı. Hücreler tripsin ile kaldırılarak steril falkon tüpüne alındı ve tripsin inaktivasyonu için serum içeren ortam eklendi. Hücre barındıran falkon tüpleri 300 g'de 5 dakika boyunca santrifüj edildi. Geride kalan hücre pelleti üzerine $1 \mathrm{~mL}$ yıkama tamponu eklenerek örnekler yıkandı. Santrifüj ve yıkama basamakları tekrarlandı. Yıkama işlemi tamamlandıktan sonra, hücrelere $125 \mu \mathrm{L}$ A solüsyonu eklendi. Örnekler oda sıcaklığında 10 dakika boyunca inkübe edildi. A solüsyonu örneklerden çekilmeden, 100 $\mu \mathrm{L}$ B solüsyonu eklendi ve inkübasyon basamağı tekrarlandı. $100 \mu \mathrm{L}$ soğuk $\left(2-8{ }^{\circ} \mathrm{C}\right.$ arasında) $\mathrm{C}$ solüsyonu örneklere eklenerek buzdolabında $\left(+4{ }^{\circ} \mathrm{C}\right)$ inkübe edildi. Örnekler flow sitometride 3 saat içerisinde okutuldu.

\section{miRNA ifadesinin belirlenmesi}

EA'nın saptanan $\mathrm{IC}_{50}$ konsantrasyonu 72 saat uygulanan ve herhangi bir uygulamaya maruz bırakılmayan meme kanseri kök hücrelerinden total RNA izolasyonu yapıldı. Total RNA izolasyonu için Qiagen miRNeasy mini kit (Qiagen, Hilden, Germany) kullanıldı. Deney basamakları üretici firmanın protokolüne göre gerçekleştirildi. EA uygulanan ve uygulanmayan hücrelerden izole edilen total RNA miktarı Thermo Nanodrop 1000 spektrofotometre (Thermo Scientific, Wilmington, USA) ile ölçüldü. İzole edilen total RNA'ların yalnızca olgun miRNA'ları cDNA'ya sentezlendi. Total RNA örneklerindeki olgun miRNA'ların cDNA'ya çevrimi için miScript // reverse transcriptase RT kit (Qiagen, Hilden, Germany) kullanıldı. cDNA sentez basamağında reaksiyon içeriği ve deney basamakları üretici firmanın protokolüne göre gerçekleştirildi. cDNA sentezini gerçekleştirmek için örnekler $37^{\circ} \mathrm{C}$ 'de 1 saat inkübe edildi. Ters transkriptaz (revers transcriptase) enziminin inaktivasyonu için sıcaklık $95^{\circ} \mathrm{C}$ 'ye yükseltildi ve örnekler 5 dakika boyunca inkübe edildi.

Olgun miRNA'lardan cDNA kalıpları elde edildikten sonra RT-PCR array aşamasına geçildi. EA uygulamasına bağlı olarak gözlenecek miRNA ifade profili değişimi miScript miRNA PCR Array Human Breast Cancer (kat no: MIHS-109Z, Qiagen, Germany) ile tanımlandı. RT-PCR array kuyucuklu plakaları meme kanseri ile ilişkili fonksiyonu bilinen 84 miRNA'ya göre tasarlandı. Her bir kuyucuk farklı bir miRNA'ya ait PCR primerini içermektedir. PCR reaksiyon karışımı $1.375 \mathrm{~mL}$ 2X Quanti Tect SYBR Green PCR, $0.275 \mathrm{~mL}$ 10X miScript Universal solüsyonu, $1 \mathrm{~mL}$ RNase içermeyen su ve $40 \mu \mathrm{L}$ cDNA ile hazırlandı. PCR karışımı hazırlandıktan sonra 96 kuyucuklu plakalara aktarıldı. Ardından RT-PCR reaksiyonu başlatıldı. RT-PCR reaksiyonunun ısıl koşulları Tablo-1'de yer almaktadır. Veri analizinde $2^{-\Delta \Delta C t}$ formülü kullanıldı. SNORD61, SNORD68, SNORD72, SNORD95, SNORD96A ve RNU6-2 miRNA genleri normalizasyon için kontrol genleri olarak seçildi. İfade profili saptanan miRNA'ların sinyal yolakları içerisindeki ortak etkisi DIANA miRPath v2.0 veri tabanı ile incelendi (23). Kullanılan veri tabanı, Tarbase veri tabanı üzerinden olası miRNA-mRNA ilişkisini göstermekle birlikte miRNA hedefindeki sinyal yolaklarını da KEGG veri tabanı üzerinden sergilemektedir (23). Çoklu miRNA sayısının ortak hedef aldığı sinyal yolağına ilişkin $p$ değeri, veri tabanı tarafından Fisher'ın kombine olasılık yöntemi (Fisher's 
combined probability method) ile bulundu (23). p değeri 0.05 'den küçük olan sinyal yolağı-miRNA sayısal etkileşimi anlamlı olarak kabul edildi.

Tablo-1. RT-PCR İçin Uygulanan Isı Koşulları

\begin{tabular}{lcc}
\hline Basamak & Süre & Sıcaklık \\
\hline $\begin{array}{l}\text { Ön inkübasyon } \\
\text { Döngü (45X) }\end{array}$ & 15 dakika & $95^{\circ} \mathrm{C}$ \\
Denatürasyon & 15 saniye & $94^{\circ} \mathrm{C}$ \\
Bağlanma & 30 saniye & $55^{\circ} \mathrm{C}$ \\
Sentez & 30 saniye & $70^{\circ} \mathrm{C}$ \\
\hline
\end{tabular}

\section{Bulgular}

Elajik asidin sitotoksik etkisi

EA'nın $100 \mu \mathrm{M}, 50 \mu \mathrm{M}, 25 \mu \mathrm{M}, 12.5 \mu \mathrm{M}, 6.25 \mu \mathrm{M}, 3.125$ $\mu \mathrm{M}$ ve $1.6 \mu \mathrm{M}$ 'lık konsantrasyon aralıklarındaki sitotoksik etkisi (24, 48 ve 72 saatlik) meme kanseri kök hücre hattında araştırıımıştır. İlk 24 saatlik uygulamada, EA'nın meme kanseri kök hücreleri üzerinde her hangi bir sitotoksik etkisi bulunmadı. Bununla birlikte, 48. ve 72 . saatlerde meme kanseri kök hücreleri üzerinde sitotoksik etki gözlendi. EA'nın 48. ve 72 . saatlerde saptanan $I_{50}$ konsantrasyonu 24.8 $\mu$ M'dır (Şekil-1).

\section{Elajik asit uygulaması}

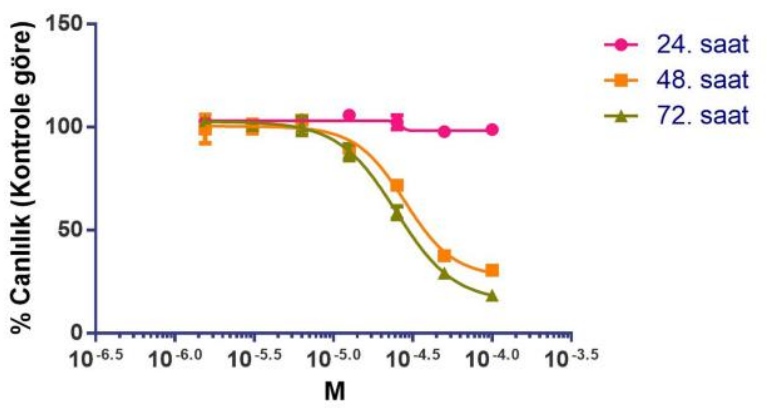

Şekil-1. Elajik asidin meme kanseri kök hücrelerinde 24., 48. ve 72. saatlerdeki sitotoksik etkisi. Elajik asidin 48. ve 72 saatlerdeki $\mathrm{IC}_{50}$ konsantrasyonu $24.8 \mu \mathrm{M}$ 'dır.

\section{Elajik asit apoptozu indüklemez}

Meme kanseri kök hücrelerine $25 \mu \mathrm{M}$ EA uygulanarak 24,48 ve 72 . saatlerdeki apoptototik hücre yüzdeleri flow sitometri ile ölçüldü. EA uygulanmayan kontrol grubunda canlı hücre yüzdesi \%99.5 iken apoptotik hücre yüzdesi $\% 0.5$ olarak saptandı. $25 \mu \mathrm{M}$ EA uygulanan meme kanseri kök hücrelerinde 1. gün, 2. gün ve 3 . gün sonunda canlı hücre yüzdeleri sırasıyla \%99.2, \%100 ve \%99.8 olarak saptandı. EA meme kanseri kök hücrelerinde apoptozu indüklememektedir (Şekil-2).

\section{Elajik asit S fazı bloğu etkenidir}

Hücre döngüsünün belirlenmesinde $25 \mu \mathrm{M}$ EA 24, 48 ve 72 saatlik zaman periyodlarıyla meme kanseri kök hücrelerine uygulanmıştır. EA uygulanmayan hücreler kontrol grubu olarak belirlendi. EA uygulanan hücrelerin G1 evresi yüzde oranı azalırken $S$ evresi yüzde oranı arttı. Kontrol grubunda hücrelerin $S$ evresi yüzdesi \%14.5 iken, EA uygulanan hücrelerde 1. gün, 2. gün ve 3. gün sonunda $S$ evresi yüzdeleri sırasıyla $\% 26.8$, \%28.5 ve \%35.3 olarak saptandı. EA'nın meme kanseri kök hücrelerinde $S$ evresi bloğuna neden olduğu bulundu (Şekil-3). a

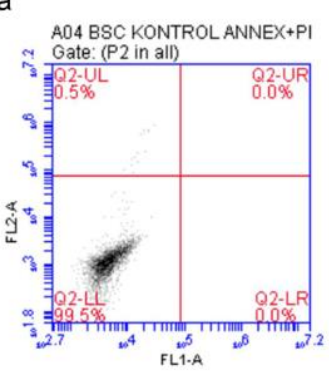

C

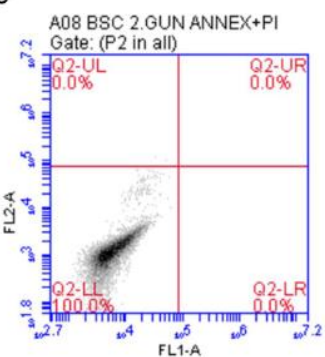

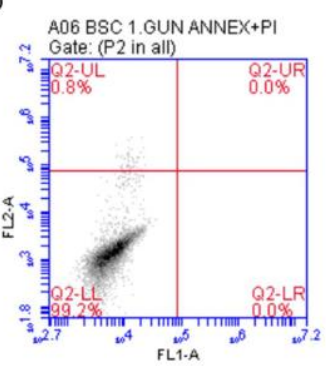

d

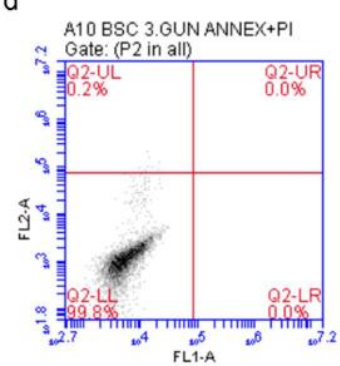

Şekil-2. Elajik asid uygulamasının 1. gün (b), 2. gün (c) ve 3. gündeki (d) apoptotik etkisi. Elajik asit uygulanmayan meme kanseri kök hücreleri (a) kontrol grubu olarak kullanıldı. Elajik asidin apoptozu indükleyici etkisi gözlenmedi.

Elajik asit uygulaması sonrası değişmiş miRNA ifade profili

Yirmi beş $\mu \mathrm{M}$ EA uygulanan meme kanseri kök hücrelerinde 72 saat sonrasında elde edilen miRNA ifade profili saptanmıştır. EA uygulanmayan hücreler ise kontrol olarak kullanılmıştır. hsa-miR-1, hsa-miR-182-5p, hsa-miR-200a-3p, hsa-miR-29b-3p, hsa-miR-429, hsamiR-548c-3p, hsa-miR-607 ve hsa-miR-96-5p miRNA genlerinin ifadesi saptanamadı. Bu nedenle 84 miRNA geninin 76'sının ifade profili saptandı. Bu miRNA genlerinden yalnızca hsa-miR-125b-1-3p'nin ifadesinde artış gözlendi.

EA uygulamasına bağlı olarak hsa-miR-125b-1-3p'nin ifadesi 3,59 katlık artış gösterdi. Diğer miRNA genlerinin tamamında ifade azalışı saptandı. hsa-miR-485-5p ve hsa-miR-328-3p miRNA genlerinin en fazla azalan ifadeye sahip olduğu saptandı. miRNA genlerinin listesi ve EA uygulaması sonrası oluşan ifade profilleri Şekil4'de verilmiştir. İfade azalışı gösteren miRNA'ların (10 kat ve üstü ifade azalışı) hedefindeki sinyal yolaklarının belirlenmesinde DIANA miRPath v2.0 veri tabanı kullanıldı. Veri analizi için endotelyal büyüme faktörü 
(hsa04012), kanser ilişkili (hsa05200), hücre döngüsü (hsa04115), p53 (hsa04115), insülin reseptör (hsa04910) ve TGF-beta sinyal (hsa04350) yolakları seçildi. Veri tabanında incelenen miRNA genlerinin 36'sından 17'sinde kanser ilişki sinyal yolağındaki genleri hedeflendiği saptandı ( $p=0.0000534)$. Biyoinformatik analize ilişkin veriler Şekil-5 ve Şekil-6'da sunulmuştur. a

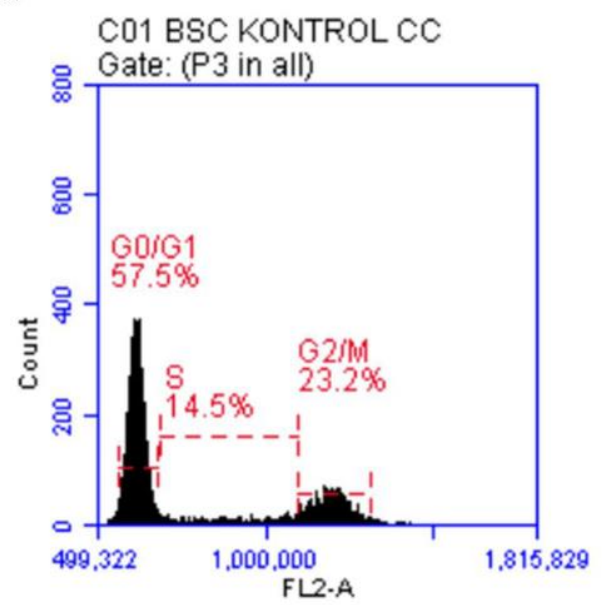

C

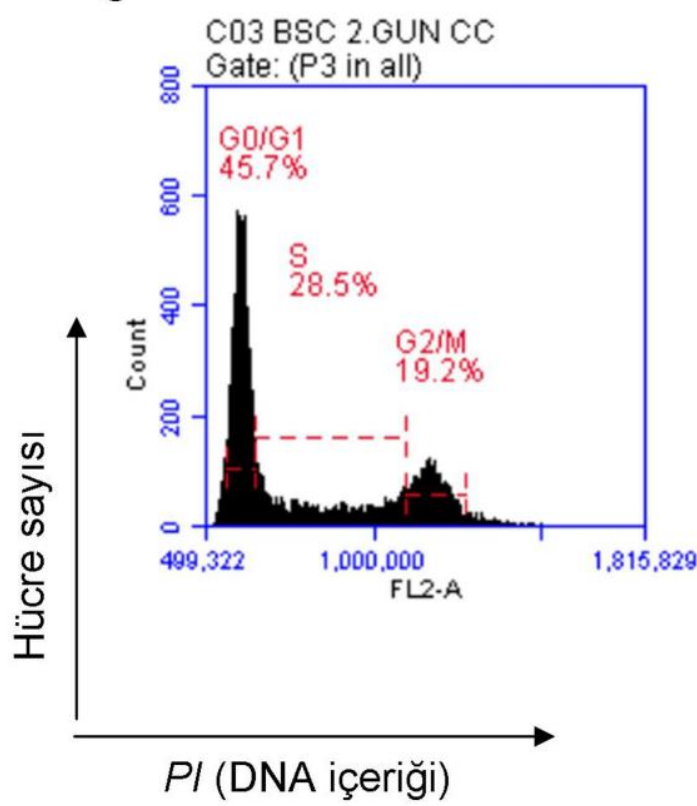

b

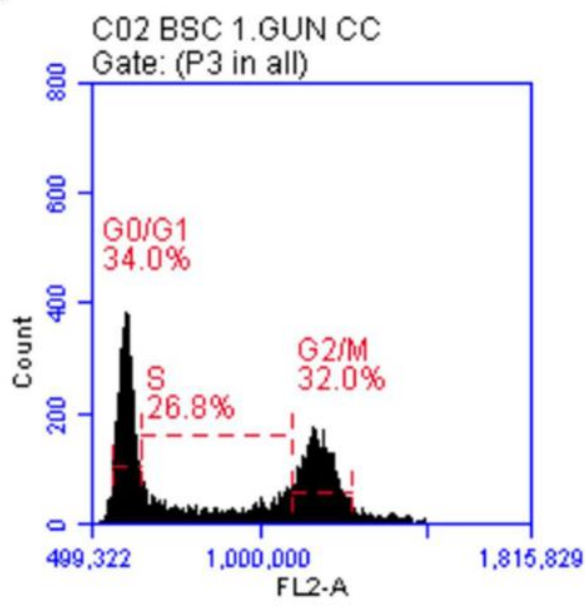

d

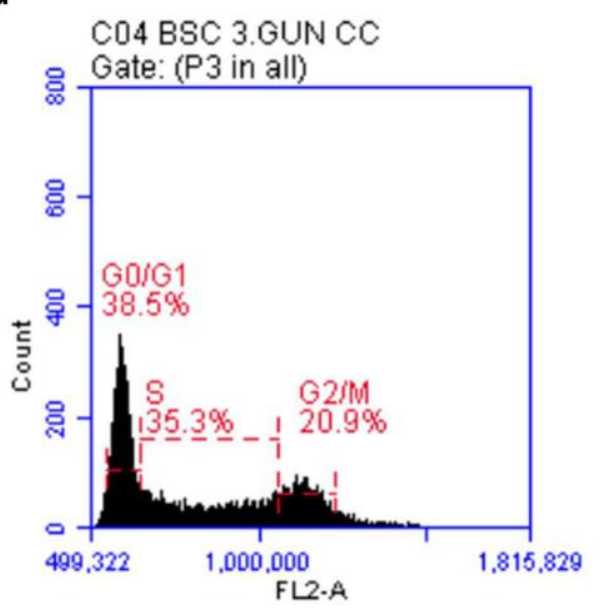

Şekil-3. Elajik asidin meme kanseri kök hücrelerinde hücre döngüsü üzerine yaptığı etki. Elajik asit uygulanmayan hücreler (a) kontrol olarak kullanıldı. Elajik asidin 24 saat (b), 48 saat (c) ve 72 saat (d) uygulandığı çalışmada $S$ fazı hücre yüzdeleri artmıştır. 


\begin{tabular}{|llllllll}
\hline hsa-let-7a-5p & hsa-miR-10a-5p & hsa-miR-141-3p & hsa-miR-181b-5p & hsa-miR-19b-3p & hsa-miR-21-5p & hsa-miR-27a-3p & hsa-miR-495-3p \\
hsa-let-7b-5p & hsa-miR-10b-5p & hsa-miR-145-5p & hsa-miR-181c-5p & hsa-miR-200b-3p & hsa-miR-210-3p & hsa-miR-27b-3p & hsa-miR-497-5p \\
hsa-let-7c-5p & hsa-miR-125b-5p & hsa-miR-148a-3p & hsa-miR-181d-5p & hsa-miR-200c-3p & hsa-miR-212-3p & hsa-miR-29a-3p & hsa-miR-613 \\
hsa-let-7d-5p & hsa-miR-125b-1-3p & hsa-miR-152-3p & hsa-miR-186-5p & hsa-miR-202-3p & hsa-miR-214-3p & hsa-miR-29c-3p & hsa-miR-7-5p \\
hsa-let-7e-5p & hsa-miR-128-3p & hsa-miR-155-5p & hsa-miR-18a-5p & hsa-miR-203a & hsa-miR-22-3p & hsa-miR-31-5p ha hsa-miR-93-5p \\
hsa-let-7f-5p & hsa-miR-129-5p & hsa-miR-15a-5p & hsa-miR-193b-3p & hsa-miR-204-5p & hsa-miR-222-3p & hsa-miR-328-3p ha-miR-98-5p \\
hsa-let-7g-5p & hsa-miR-130a-3p & hsa-miR-15b-5p & hsa-miR-195-5p & hsa-miR-205-5p hsa-miR-223-3p & hsa-miR-340-5p \\
hsa-let-7i-5p & hsa-miR-130b-3p & hsa-miR-16-5p & hsa-miR-199b-3p & hsa-miR-206 & hsa-miR-25-3p & hsa-miR-424-5p \\
hsa-miR-100-5p & hsa-miR-132-3p & hsa-miR-17-5p & hsa-miR-199a-5p & hsa-miR-20a-5p & hsa-miR-26a-5p & hsa-miR-485-5p \\
hsa-miR-107 & hsa-miR-140-5p & hsa-miR-181a-5p & hsa-miR-19a-3p & hsa-miR-20b-5p & hsa-miR-26b-5p & hsa-miR-489-3p \\
\hline
\end{tabular}

b

\begin{tabular}{|c|c|c|c|c|c|c|c|}
\hline$-1,44$ & $-22,08$ & $-7,92$ & $-9,95$ & $-5,79$ & $-21,78$ & $-7,18$ & $-10,16$ \\
\hline$-3,77$ & $-13,04$ & $-8,66$ & $-4,48$ & $-1,92$ & $-21,18$ & $-2,58$ & $-9,68$ \\
\hline$-23,50$ & $-12,77$ & $-2,59$ & $-9,41$ & $-20,89$ & $-25,36$ & $-6,94$ & $-29,75$ \\
\hline$-11,51$ & 3,59 & $-18,70$ & $-9,48$ & $-1,91$ & $-1,28$ & $-7,59$ & $-13,59$ \\
\hline$-1,34$ & $-4,91$ & $-8,78$ & $-5,44$ & $-14,67$ & $-17,20$ & $-20,60$ & $-18,06$ \\
\hline$-1,85$ & $-11,35$ & $-16,28$ & $-8,25$ & $-12,77$ & $-15,61$ & $-71,74$ & $-6,52$ \\
\hline$-17,57$ & $-27,00$ & $-24,00$ & $-2,32$ & $-12,77$ & $-25,90$ & $-9,35$ & \\
\hline$-2,42$ & $-4,87$ & $-31,23$ & $-21,93$ & $-8,84$ & $-16,28$ & $-37,65$ & \\
\hline$-10,44$ & $-28,14$ & $-12,25$ & $-1,28$ & $-4,24$ & $-5,56$ & $-91,43$ & \\
\hline$-27,00$ & $-3,08$ & $-6,04$ & $-8,37$ & $-3,15$ & $-3,42$ & $-6,25$ & \\
\hline
\end{tabular}

Azalış Artış

Şekil-4. miRNA ifadelerinin elajik asit 72 saat uygulamasından sonra meme kanseri kök hücrelerindeki ifade profilleri. Kırmızı renk ifade azalışını, yeşil renk ise ifade artışını temsil etmektedir.

Sinyal yolaklarında hedeflenen gen sayısı

miRNA
\begin{tabular}{|l|}
\hline hsa-let-7d-5p \\
hsa-miR-107 \\
hsa-miR-10a-5p \\
hsa-miR-125b-5p \\
hsa-miR-132-3p \\
hsa-miR-15a-5p \\
hsa-miR-15b-5p \\
hsa-miR-16-5p \\
hsa-miR-17-5p \\
hsa-miR-200c-3p \\
hsa-miR-205-5p \\
hsa-miR-21-5p \\
hsa-miR-212-3p \\
hsa-miR-22-3p \\
hsa-miR-222-3p \\
hsa-miR-7-5p \\
hsa-miR-93-5p \\
\hline
\end{tabular}

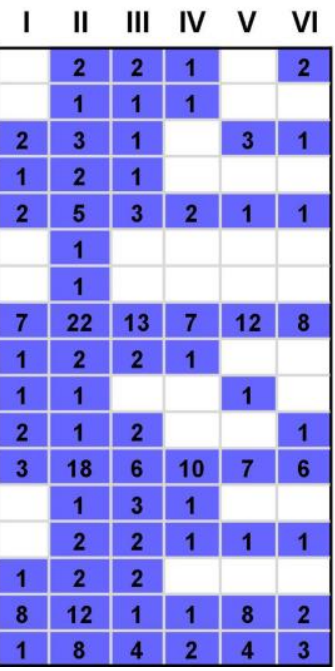

\begin{tabular}{lcc}
\hline \multicolumn{1}{c}{$\begin{array}{c}\text { Sinyal yolağı } \\
\text { (KEGG pathway database) }\end{array}$} & P değeri & miRNA \\
\hline I. ErbB (EGF) sinyal yolağı (hsa04012) & 0,0000119 & 11 \\
II. Kanser iliş̧ili sinyal yolakları (hsa05200) & 0,0000534 & 17 \\
III. Hücre döngüsü (hsa04110) & 0,0003888142 & 14 \\
IV. p53 sinyal yolağı (hsa04115) & 0,00369382 & 10 \\
V. İnsülin reseptör ilişkili sinyal yolağı (hsa04910) & 0,005266395 & 8 \\
VI. TGF-beta sinyal yolağı (hsa04350) & 0,01245914 & 9 \\
\hline
\end{tabular}

Şekil-5. On kat ve üstü ifade azalışı sergileyen miRNA'ların hedeflediği sinyal yolakları. Şekilde mor kutucuk içerisindeki rakamlar her bir miRNA'nın belirtilen sinyal yolağı içerisindeki protein sentezleyen hedef gen sayısını vermektedir. Bazı miRNA'lar sentez yolağı içerisinde birden fazla mRNA'yı hedefleyebilmektedir. Şekildeki p değeri listedeki sinyal yolağı ve sinyal yolağını hedefleyen miRNA sayısı ilişkisini belirtmektedir. 


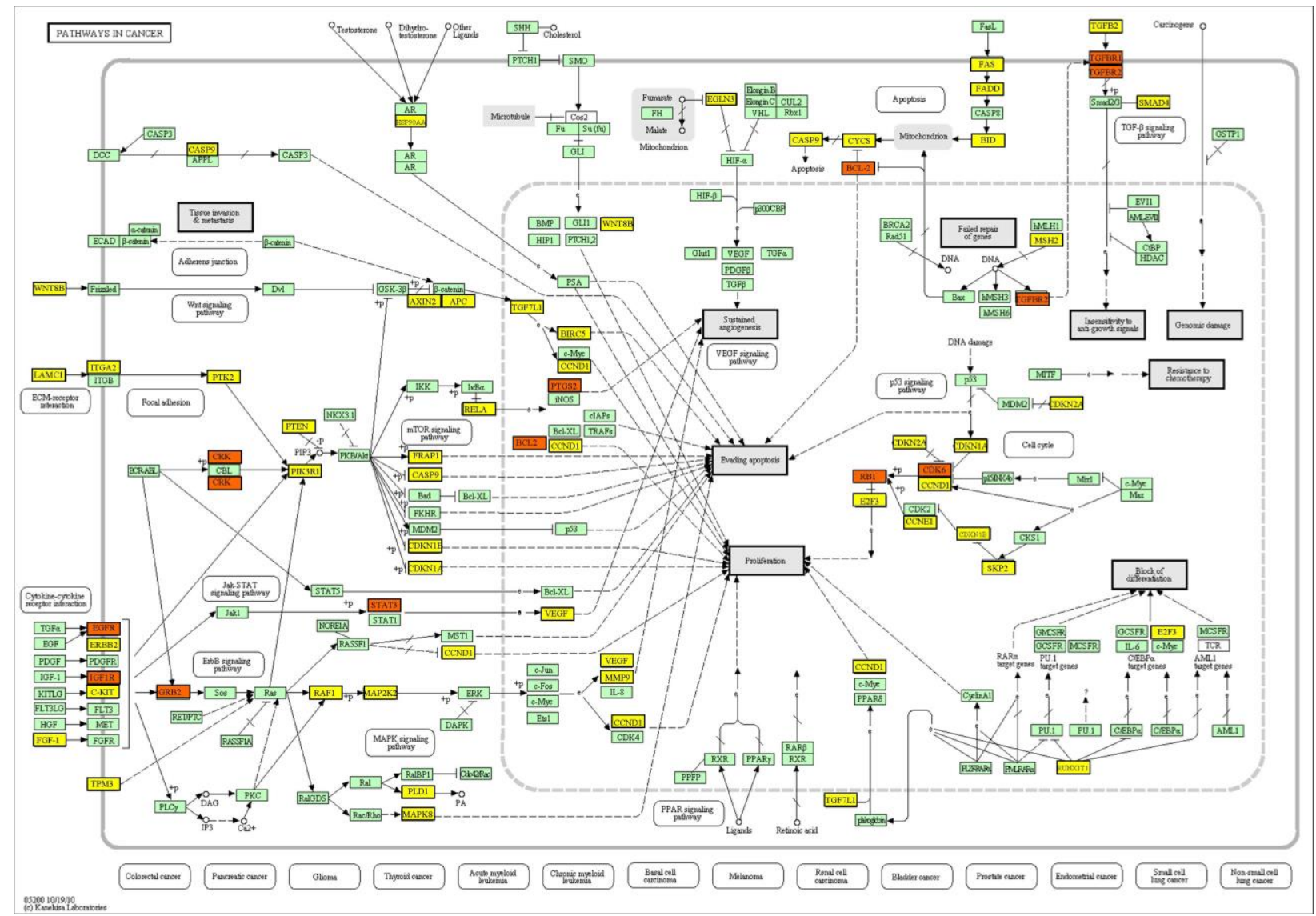

Şekil-6. Elajik asit uygulamasına bağlı olarak ifadesi azalan miRNA'ların kanser ilişkili sinyal yolağı (hsa05200) içerisindeki gen hedefleri. Yeşil renk genlerin miRNA hedefi olmadığını göstermektedir. Sarı renk, sinyal yolağındaki genin analiz edilen miRNA'lardan sadece birinin hedefi olduğunu göstermektedir. Turuncu renk, sinyal yolağındaki genin analiz edilen miRNA'lardan birden fazlasının hedefi olduğunu göstermektedir.

\section{Tartışma}

Çeşitli çalışmalarda, bitkisel kökenli doğal bir fenolik molekül olan EA'nın hücreler üzerinde anti-oksidan ve anti-inflamatuar etkilere sahip olduğu vurgulanmaktadır $(11,13,24)$. EA ve diğer fito-kimyasalları içeren bitki ekstraktları meme kanseri hücrelerinde bölünmeyi durdurmakta ve apoptozu indüklemektedir $(10,14)$. Ekstrakt içeriklerinin HPLC metodu ile incelenmesi, EA'nın diğer moleküllere göre daha fazla bulunduğunu ortaya çıkarmıştır $(6,25)$. EA'nın tek başına meme kanseri hücrelerine uygulandığı çalışmalarda da hücre döngüsünün baskılandığı ve apoptozun meydana geldiği bildirilmiştir (14). Meme kanseri hücrelerinin aşırı bölünmesinden sorumlu aromataz ve telomeraz enzimlerinin aktiviteleri de EA tarafından düşürülmektedir $(26,27)$. Buna ilaveten, EA meme kanseri tümör modelinde hücre göçü ve yeni damar oluşumunu engellemektedir (17). EA meme kanseri hücreleri üzerinde kemoprevantif ajan etkisi göstermesine rağmen, ilaç direnci mekanizmasına sahip meme kanseri kök hücreleri üzerindeki etkisi farklı veya sınırlı olabilir.
Bu çalışmada, EA'nın meme kanseri kök hücreleri üzerindeki etkinliği araştırılmıştır. EA'nın 24, 48 ve 72 saat boyunca uygulandığı sitotoksite deneyinde, 24. saatte herhangi bir sitotoksik etki saptanmadı. Meme kanseri kök hücrelerinde uygulama zamanının artışına bağlı olarak EA'nın sitotoksik etki gösterdiği bulundu. 48 . ve 72. saatlerdeki $I C_{50}$ konsantrasyonu $24,8 \mu \mathrm{M}$ olarak saptandı. Chen ve ark. (14), EA'nın ilk 24 saat içerisinde MCF-7 meme kanseri hücreleri için sitotoksik $\left(\mathrm{IC}_{50}=\right.$ $66.18 \mu \mathrm{M} ; 20 \mu \mathrm{g} / \mathrm{mL}$ ) etkiye sahip olduğunu bildirmiştir. Dai ve ark. (28), wnt-1 genini içeren fare meme tümör virüsü (mouse mammary tumor virüs) yardımıyla fare meme kanser kök hücresi elde etmişlerdir. Fare meme kanseri kök hücrelerinde ise, EA 24. saatte sitotoksik etki oluşturmamasına karşın 48. ve 72. saatlerde sitotoksik etki oluşturmuştur (28). Bu bakımdan, EA meme kanseri hücreleri ve meme kanseri kök hücreleri arasında farklı sitotoksik etkiye sahip olabilir. Chen ve ark. (14), çalışmasına benzer bir şekilde, Dai ve ark. (28) da EA'nın fare meme kanseri kök hücrelerinde apoptozu ve G0/G1 hücre bloğunu arttırmasının sitotoksik etkiye neden olduğunu savunmaktadır. 
$\mathrm{Bu}$ çalışmada, saptanan $\mathrm{IC}_{50}$ konsantrasyonundaki $\mathrm{EA}$ meme kanseri kök hücrelerine 24,48 ve 72 saat uygulandıktan sonra apoptoz ve hücre döngüsü analizi yapıldı. Sitotoksik konsantrasyon uygulanmasına rağmen, meme kanseri kök hücrelerinin apoptotik hücre yüzdesinde artış meydana gelmedi. Bununla birlikte, EA'nın hücre döngüsünü $S$ fazında durdurduğu saptandı. Dai ve ark. (28) aksine, EA'nın apoptozu indüklemediği ve sadece hücre döngüsünde etkili olduğu saptandı. Dai ve ark. (28), sitoktoksite dışındaki diğer çalışmalarını, nar bitkisinden elde edilen bitki ekstraktını fare meme kanseri kök hücrelerine uygulayarak gerçekleştirmiştir. EA'nın bitki ekstraktı içerisindeki farklı fito-kimyasallar ile sinerjistik etki gösterdiği bilinmektedir $(29,30)$. Dolasıyla, EA'nın tek başına meme kanseri kök hücreleri üzerinde apoptotik etkisi olmayabilir. Bu çalışmadan elde edilen veriler, EA'nın meme kanseri kök hücrelerinde sitotoksik etkisinin değil sitostatik etkisi olabileceğini göstermektedir.

Hücresel farklılaşma, hücre invazyonu ve göçü, ilaç direnci, apoptozis ve kök hücre özelliklerinin korunması gibi birçok farklı mekanizmada miRNA'lar hedefindeki genlerin ifadesini düzenleyerek rol oynamaktadır (31-35). miRNA'ların ifadesi meme kanseri hücreleri ve meme kanseri kök hücreleri arasında farklılıklar sergilemektedir (20). Bu nedenle, meme kanseri kök hücrelerindeki miRNA'ların anormal ifadeleri EA'nın etkinlik farklıığının bir nedeni olabilir. EA'nın 72 saat uygulanmasına bağlı olarak meme kanseri ilişkili miRNA'ların ifade profilleri saptandı. EA uygulamasına bağlı olarak sadece hsa-miR125b-1-3p'nin ifadesi artış gösterdi. Diğer miRNA genlerinin tamamında ise ifade azalışı saptandı. Ifadesi 10 kat ve üstü azalış sergileyen 36 miRNA'nın hedefledikleri sinyal yolakları DIANA miRPath v2.0 veri tabanı ile incelendi. Bioinformatik inceleme sonucunda, 36 miRNA'dan 11'inin ErbB sinyal yolağı $(p=0.0000119)$, 17 'sinin kanser ilişkili sinyal yolağı $(p=0.0000534)$, 14 'ünün hücre döngüsü ( $p=0.00038)$, 10'nunun $p 53$ sinyal yolağı $(p=0.0036), 8$ 'inin insülin reseptör sinyal yolağı $(p=$ $0.0052)$ ve 9'unun TGF- $\beta$ sinyal yolağındaki $(p=0.012)$ ilişkili genleri hedeflediği saptandı.

Let-7 ailesi miRNA'ların kötü prognoz gösteren meme kanseri hastalarında daha düşük ifade edildiği bulunmuştur (36). Kanser kök hücreleri, tümör içerisindeki diğer hücre popülasyonlarına göre Let-7 ailesi miRNA'ları daha düşük düzeyde ifade etmektedir (20). Bununla birlikte, Let-7 ailesi miRNA'ların düşmesi normal meme kanseri hücrelerini kanser kök hücrelerine transforme etmektedir $(37,38)$. Let-7 ailesine ait miRNA'lar Oct4, Sox2, Nanog ve Tcf3 gibi genlerin mRNA ifadelerini düzenleyerek kök hücrelerin farklılaşmasını düzenlemektedir (39). Yapılan bu çalışmada, let-7 ailesine ait tüm olgun miRNA'ların (let-7a-5p, let-7b-5p, let-7c-5p, let$7 d-5 p$ gibi) ifadesi EA'ya bağlı olarak düşmüştür. EA, Let7 ailesi miRNA'ların ifadesini düşürerek meme kanseri kök hücre özelliklerinin korunmasına neden olabilir. Let-7 miRNA'ları siklin D1 ifadesini baskılayarak Akt1'in fosforilasyonunu azaltmaktadır (40). Bu nedenle, Let-7 radyasyon ile indüklenmiş tümör baskılanmasını arttırmaktadır (40). EA'nın Let-7 ailesine ait olgun miRNA'ların ifadelerini düşürmesi ayrıca radyoterapiye karşı direncin oluşmasında da etkili olabilir.

TGF- $\beta$ sinyal yolağı, ErbB sinyal yolağı gibi diğer sinyal yolaklarıyla ilişkili bir biçimde epitelyal-mezenkimal geçiş, apoptoz, hücre göçü ve metastazda rol oynamaktadır (41). miRNA-200 ailesi (miR-200a/b/c) miRNA'ların TGF- $\beta$ sinyal yolağını düzenleyerek hücre transformasyonu, hücre proliferasyonu, hücre göçü, tümör büyümesi ve metastaz üzerinde güçlü baskılayıcı etkileri olduğu gösterilmiştir (42). miRNA-200 ailesi üyelerinin meme kanserinde epitelyal mezenkimal geçiş mekanizmasının baskılayıcıları olduğu bilinmektedir. miRNA ailesi üyelerinin ifadesi, kök hücre fonksiyonunun devamlıı̆̆ının korunabilmesi için meme kanseri kök hücrelerinde düşüktür $(21,43-45)$. Bu çalışmada, EA uygulaması meme kanseri kök hücrelerinde miRNA-200 aile üyesi olan miR200b-3p ve miR-200c-3p'nin ifadelerini düşürmüştür. EA'nın meme kanseri kök hücrelerindeki genel etkisi kanser kök hücre özelliklerinin korunmasını sağlamak olabilir. Kanser kök hücreleri, tümör dokusu içerisindeki diğer alt popülasyonlara göre kemoterapi ajanlarına daha fazla direnç oluşturduğu bilinmektedir. miR-200c, miR27a, miR-181a, miR-328 ve miR-145 hücrelerde direnç mekanizmasından sorumlu ATP bağlayan kaset proteinleri ABCB1 ve ABCG2'yi baskılamaktadır (34). Bu çalışmada, bu miRNA'ların olgun formlarının ifadesi EA'ya bağlı olarak düşmüştür.

\section{Sonuç}

Bu çalışmada, EA'nın meme kanseri kök hücrelerindeki miRNA ifade değişimleri üzerine etkisi ilk kez gösterilmiştir. EA meme kanseri hücrelerinde etkili olsa da aynı etkiye meme kanseri kök hücreleri üzerinde sahip değildir. EA meme kanseri kök hücrelerini farklılaşmadan koruyabileceği gibi bu hücreleri kemoterapi ve radyo terapiye karşı daha dirençli bir hale getirebilir. Bu nedenle, kanser tedavisi gören meme kanseri hastalarında günlük diyette EA içeren besinlerin çıkartılması önerilebilir.

\section{Çıkar çatışması}

Yazarlar bu çalışma ile ilgili herhangi bir çıkar çatışması olmadığını belirtmektedir.

\section{Açıklamalar}

$\mathrm{Bu}$ çalışma finansal olarak EBILTEM-TTO teknoloji transfer ofisi proje destek birimi tarafından desteklenmiştir (proje numaraları: 13-KSUAM-001 ve 13-KSUAM-002). Belirtilen projeler Ege Üniversitesi Kanserle Savaş Araştırma ve Uygulama Merkezi (KSUAM) adına desteklenmiştir. 


\section{Kaynaklar}

1. Siegel RL, Miller KD, Jemal A. Cancer statistics, 2015. CA Cancer J Clin 2015;65(1):5-29.

2. Liu H, Liu Y, Zhang JT. A new mechanism of drug resistance in breast cancer cells: Fatty acid synthase overexpressionmediated palmitate overproduction. Mol Cancer Ther 2008;7(2):263-70.

3. Barok M, Joensuu H, Isola J. Trastuzumab emtansine: Mechanisms of action and drug resistance. Breast Cancer Res 2014;16(2):209.

4. Hayes EL, Lewis-Wambi JS. Mechanisms of endocrine resistance in breast cancer: An overview of the proposed roles of noncoding RNA. Breast Cancer Res 2015;17:40.

5. Weigelt B, Peterse JL, van 't Veer LJ. Breast cancer metastasis: Markers and models. Nat Rev Cancer 2005;5(8):591-602.

6. Lee J, Kim YS, Lee J, et al. Walnut phenolic extract and Its bioactive compounds suppress colon cancer cell growth by regulating colon cancer stemness. Nutrients 2016;8(7):E439.

7. Ambigaipalan $\mathrm{P}$, de Camargo AC, Shahidi F. Phenolic compounds of pomegranate byoproducts (outer skin, mesocarp, divider membrane) and their antioxidant activities. J Agric Food Chem 2016;64(34):6584-604.

8. Hacke AC, Granato D, Maciel LG, et al. Jabuticaba (Myrciaria cauliflora) seeds: Chemical characterization and extraction of antioxidant and antimicrobial compounds. J Food Sci doi: 10.1111/1750-3841.13405.

9. Saleem A, Husheem M, Harkonen P, Pihlaja K. Inhibition of cancer cell growth by crude extract and the phenolics of Terminalia chebula retz. fruit. J Ethnopharmacol 2002;81(3):327-36.

10. Wang Z, Loo WT, Wang N, et al. Effect of Sanguisorba officinalis $L$ on breast cancer growth and angiogenesis. Expert Opin Ther Targets 2012;16 (Suppl 1):79-89.

11. Guruvayoorappan C, Kuttan G. (+)-Catechin inhibits tumour angiogenesis and regulates the production of nitric oxide and TNFalpha in LPS-stimulated macrophages. Innate immunity 2008;14(3):160-74.

12. Iniguez-Franco F, Soto-Valdez H, Peralta E, Ayala-Zavala JF, Auras R, Gamez-Meza N. Antioxidant activity and diffusion of catechin and epicatechin from antioxidant active films made of poly(L-lactic acid). J Agric Food Chem 2012;60(26):6515-23.

13. Siraj MA, Shilpi JA, Hossain MG, et al. Anti-inflammatory and antioxidant activity of Acalypha hispida leaf and analysis of its major bioactive polyphenols by HPLC. Adv Pharm Bull 2016;6(2):275-83.

14. Chen HS, Bai MH, Zhang T, Li GD, Liu M. Ellagic acid induces cell cycle arrest and apoptosis through TGF-beta/Smad3 signaling pathway in human breast cancer MCF-7 cells. Int J Oncol 2015;46(4):1730-8.

15. Shi L, Gao X, Li X, et al. Ellagic acid enhances the efficacy of PI3K inhibitor GDC-0941 in breast cancer cells. Curr Mol Med 2015;15(5):478-86.

16. Zhang T, Chen HS, Wang LF, et al. Ellagic acid exerts anti-proliferation effects via modulation of Tgf-beta/Smad3 signaling in MCF-7 breast cancer cells. Asian Pac J Cancer Prev 2014;15(1):273-6.

17. Wang N, Wang ZY, Mo SL, et al. Ellagic acid, a phenolic compound, exerts anti-angiogenesis effects via VEGFR-2 signaling pathway in breast cancer. Breast Cancer Res Treat 2012;134(3):943-55.

18. Dawood S, Austin L, Cristofanilli M. Cancer stem cells: Implications for cancer therapy. Oncology (Williston Park) 2014;28(12):1101-7.

19. Salvador MA, Birnbaum D, Charafe-Jauffret E, Ginestier C. Breast cancer stem cells programs: enter the (non)-code. Brief Funct Genomics 2016;15(3):186-99.

20. Yu F, Yao H, Zhu P, et al. Llet-7 regulates self renewal and tumorigenicity of breast cancer cells. Cell 2007;131(6):1109-23.

21. Shimono Y, Mukohyama J, Nakamura S, Minami H. MicroRNA regulation of human breast cancer stem cells. J Clin Med doi: $10.3390 / \mathrm{jcm} 5010002$.

22. Munagala R, Aqil F, Vadhanam MV, Gupta RC. MicroRNA 'signature'during estrogen-mediated mammary carcinogenesis and its reversal by ellagic acid intervention. Cancer Lett 2013;339(2):175-84.

23. Vlachos IS, Kostoulas N, Vergoulis T, et al. DIANA miRPath v.2.0: Investigating the combinatorial effect of microRNAs in pathways. Nucleic Acids Res 2012 [cited 04 Sept 2016]. Available from: $h$ ttp://nar.oxfordjournals.org/content/40/W1/W498.long

24. Atta Ur R, Ngounou FN, Choudhary Ml, et al. New antioxidant and antimicrobial ellagic acid derivatives from Pteleopsis hylodendron. Planta Med 2001;67(4):335-9.

25. Venkataramanamma D, Aruna P, Singh RP. Standardization of the conditions for extraction of polyphenols from pomegranate peel. J Food Sci Technol 2016;53(5):2497-503.

26. Adams LS, Zhang Y, Seeram NP, Heber D, Chen S. Pomegranate ellagitannin-derived compounds exhibit antiproliferative and antiaromatase activity in breast cancer cells in vitro. Cancer Prev Res 2010;3(1):108-13.

27. Strati A, Papoutsi Z, Lianidou E, Moutsatsou P. Effect of ellagic acid on the expression of human telomerase reverse transcriptase (hTERT) alpha+beta+transcript in estrogen receptor-positive MCF-7 breast cancer cells. Clin Biochem 2009;42(13-14):1358-62.

28. Dai Z, Nair V, Khan M, Ciolino HP. Pomegranate extract inhibits the proliferation and viability of MMTV-Wnt-1 mouse mammary cancer stem cells in vitro. Oncol Rep 2010;24(4):1087-91.

29. Kumar D, Basu S, Parija L, et al. Curcumin and ellagic acid synergistically induce ROS generation, DNA damage, p53 accumulation and apoptosis in HeLa cervical carcinoma cells. Biomed Pharmacother 2016;81(1):31-7.

30. Mertens-Talcott SU, Percival SS. Ellagic acid and quercetin interact synergistically with resveratrol in the induction of apoptosis and cause transient cell cycle arrest in human leukemia cells. Cancer Lett 2005;218(2):141-51.

31. Garofalo M, Croce CM. Role of microRNAs in maintaining cancer stem cells. Adv Drug Deliv Rev 2015;81:53-61.

32. Ali Hosseini Rad SM, Bavarsad MS, Arefian E, Jaseb K, Shahjahani M, Saki N. The Role of microRNAs in Stemness of Cancer Stem Cells. Oncol Rev 2013;7(1):e8.

33. Zhou N, Mo YY. Roles of microRNAs in cancer stem cells. Front Biosci (Schol Ed) 2012;1(4):810-8.

34. Gomes BC, Rueff J, Rodrigues AS. MicroRNAs and cancer drug resistance. Methods Mol Biol 2016;1395:137-62.

35. Chen W, Zhou S, Mao L, et al. Crosstalk between TGF-beta signaling and miRNAs in breast cancer metastasis. Tumour Biol 2016;37(8):10011-9. 
36. Hu X, Guo J, Zheng L, et al. The heterochronic microRNA let-7 inhibits cell motility by regulating the genes in the actin cytoskeleton pathway in breast cancer. Mol Cancer Res 2013;11(3):240-50.

37. Iliopoulos D, Hirsch HA, Struhl K. An epigenetic switch involving NF-kappaB, Lin28, Let-7 MicroRNA, and IL6 links inflammation to cell transformation. Cell 2009;139(4):693-706.

38. Iliopoulos D, Hirsch HA, Wang G, Struhl K. Inducible formation of breast cancer stem cells and their dynamic equilibrium with non-stem cancer cells via IL6 secretion. Proc Natl Acad Sci USA 2011;108(4):1397-402.

39. Melton C, Judson RL, Blelloch R. Opposing microRNA families regulate self-renewal in mouse embryonic stem cells. Nature 2010;463(7281):621-6.

40. Sun $\mathrm{H}$, Ding $\mathrm{C}$, Zhang $\mathrm{H}$, Gao J. Let7 miRNAs sensitize breast cancer stem cells to radiationinduced repression through inhibition of the cyclin D1/Akt1/Wnt1 signaling pathway. Mol Med Rep 2016 doi: 10.3892/mmr.2016.5656

41. Zhao B, Chen YG. Regulation of TGF-beta Signal Transduction. Scientifica 2014;2014:874065.

42. Humphries B, Yang C. The microRNA-200 family: small molecules with novel roles in cancer development, progression and therapy. Oncotarget 2015;6(9):6472-98.

43. Gill JG, Langer EM, Lindsley RC, et al. Snail and the microRNA-200 family act in opposition to regulate epithelial-to-mesenchymal transition and germ layer fate restriction in differentiating ESCs. Stem cells 2011;29(5):764-76.

44. Wang G, Guo X, Hong W, et al. Critical regulation of miR-200/ZEB2 pathway in Oct4/Sox2-induced mesenchymal-to-epithelial transition and induced pluripotent stem cell generation. Proc Natl Acad Sci USA 2013;110(8):2858-63.

45. Shimono Y, Zabala M, Cho RW, et al. Downregulation of miRNA-200c links breast cancer stem cells with normal stem cells. Cell 2009;138(3):592-603. 